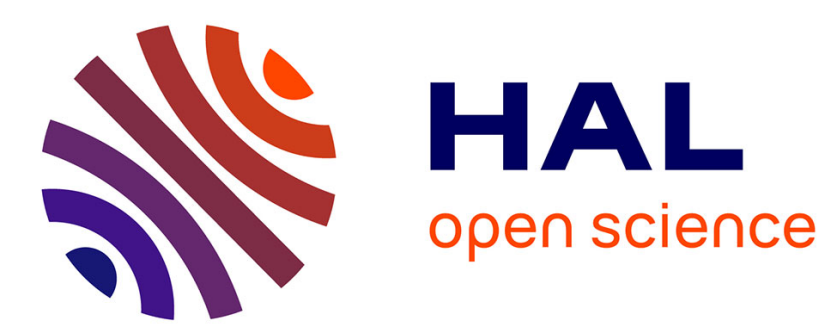

\title{
Mucins: a new family of epigenetic biomarkers in epithelial cancers
}

Isabelle van Seuningen, Audrey Vincent

\section{To cite this version:}

Isabelle van Seuningen, Audrey Vincent. Mucins: a new family of epigenetic biomarkers in epithelial cancers. Expert opinion on medical diagnostics, 2009, 3, pp.411 - 427. 10.1517/17530050902852697. hal-02905792

\section{HAL Id: hal-02905792 \\ https://hal.science/hal-02905792}

Submitted on 30 Sep 2020

HAL is a multi-disciplinary open access archive for the deposit and dissemination of scientific research documents, whether they are published or not. The documents may come from teaching and research institutions in France or abroad, or from public or private research centers.
L'archive ouverte pluridisciplinaire HAL, est destinée au dépôt et à la diffusion de documents scientifiques de niveau recherche, publiés ou non, émanant des établissements d'enseignement et de recherche français ou étrangers, des laboratoires publics ou privés. 


\section{Offprints and colour figure order form}

\section{OFFPRINTS}

You are entitled to order one set of 100 offprints at a discounted rate of: $£ 270 / \$ 530 / € 450$. These prices are only valid if the form is received before the issue goes to press.

Article details

Manuscript ID: 385441

First author: _Isabelle Van Seuningen

Title: Mucins: a new family of epigenetic biomarkers in epithelial cancers

Journal title: Expert Opinion on Medical Diagnostics Volume and issue: $3(4)$

Please tick / delete as appropriate:

$\square$ I wish to order 100 additional copies of the above article. Please charge: $£ 270$ / \$530 / €450

Delivery address:

\section{COLOUR FIGURES}

I require the following number of figures to be printed in colour:

Figure numbers:

Please charge: $£ 100 / \$ 150 / € 120$ per figure

\begin{tabular}{|l|l|l|}
\hline Offprints Cost & Colour Figures & Total Cost \\
\hline & & \\
\hline
\end{tabular}

\section{PAYMENT}

\section{Credit Card Payment:}

Credit Card $\square$ Please charge my AMEX/VISA/MasterCard (delete as appropriate)

\section{Card No}
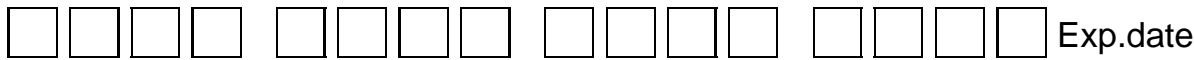

CVV number (last 3 or 4 digits on reverse of card):

Name on credit card:

Address where registered:

Signature:

Date:

All orders are accepted subject to Informa Healthcare's standard Terms and Conditions.

Please fax back completed order to: Kavi Ganeshananthan +44 (0)20 70177667

Material code: 7811 (ROW) 


\section{Journal: Expert Opinion on Medical Diagnostic (EODG)}

Title: Mucins: a new family of epigenetic biomarkers in epithelial cancers

ID: 385441

\section{Corresponding author: Isabelle Van Seuningen}

AUTHOR: Please complete the colour figure order form that accompanies your proof if you require figures to appear in colour in the print version of the journal; once you have completed your article and credit card details, email or fax the form back to the production editor.

The following queries have arisen during the editing of your manuscript. Please answer the queries by making the necessary corrections on the CATS online corrections form. Once you have added all your corrections, please press the SUBMIT button.

\begin{tabular}{|l|l|l|}
\hline Page number & Line number & Query \\
\hline 8 & $\mathbf{5 2 2}$ & $\begin{array}{l}\text { AQ1: Can these two websites be } \\
\text { added to references [81,82] in the } \\
\text { bibliography? }\end{array}$ \\
\hline 10 & 640 & AQ2: MUC2? \\
\hline $16-17$ & $\begin{array}{l}\text { AQ3: Please supply volume and page } \\
\text { numbers for ref [53, 67, 76, 102]. }\end{array}$ \\
\hline $14-17$ & $\begin{array}{l}\text { AQ4: Please provide annotations for } \\
\text { references. }\end{array}$ \\
\hline 3 & $\begin{array}{l}\text { AQ5:Fig. 1 Image is not clear. Please } \\
\text { check. }\end{array}$ \\
\hline
\end{tabular}




\section{Expert Opinion}

1. Introduction

2. Mucins and epigenetics

3. Expert opinion

\section{Mucins: a new family of epigenetic biomarkers in epithelial cancers}

\author{
Isabelle Van Seuningen ${ }^{\dagger} \&$ Audrey Vincent \\ Jean-Pierre Aubert Research Center, Epithelial Differentiation and Carcinogenesis', Inserm, U837, \\ Team 5 'Mucins, Place de Verdun, 59045 Lille cedex, France
}

Background: Epigenetic regulation of gene expression is a common feature of cancer development and progression. The search for new biomarkers and tools to detect cancer in its early stages has unveiled the usefulness of epigenetics and genes epigenetically regulated as potential targets. Among them, genes encoding mucins has been shown to be regulated by DNA methylation and histone modifications in epithelial cancer cells. These genes encode either secreted glycoproteins necessary for epithelial homeostasis or membrane-bound glycoproteins that participate in tumor progression. Objective: The important biological functions played by these large molecules in pathophysiology of the epithelia make them key genes to target to propose new therapeutic strategies and new diagnostic and/or prognostic tools in cancer. Results: In that context, the recent data regarding the epigenetic regulation of these genes are reported and their potential as biomarkers in cancer is discussed. Mucin genes are also potentially interesting to study as they may be regulated by miRNAs but also regulate miRNA activity. Conclusion: Epigenetic regulation of mucin genes is at its dawn, but there is great potential in that research to (with new technologies and high-throughput methods) provide quickly new biomarkers (diagnostic and/or prognostic), help tumor identification/classification and propose new therapeutic targets to the clinician and pathologist.

Keywords: biomarker, cancer, epigenetics, mucin

Expert Opin. Med. Diagn. (2009) 3(4):1-17

\section{Introduction}

The term 'epigenetic' refers to a heritable change in the pattern of gene expression that is driven by mechanisms other than alterations in the primary nucleotide sequence of the gene [1,2]. Epigenetic changes in the genome include DNA methylation and histone modifications (acetylation, methylation, phosphorylation, ubiquitination, sumoylation), two mechanisms that are often tightly linked in the regulation of gene expression and involved in many cellular processes [3]. For example, DNA methylation is a crucial epigenetic modification that drives embryonic development, X-chromosome inactivation, genomic imprinting and chromosome stability, whereas histone modifications govern rearrangement of chromatin structure.

DNA methylation occurs on CpG dinucleotides and follows a cell-specific profile that is established during development by DNA methyltransferases DNMT3A and DNMT3B [4] and is maintained through cell division by DNMT1 [5]. In the human genome, CpG sites are statistically underrepresented but are clustered in GC-rich regions termed $\mathrm{CpG}$ islands. These $\mathrm{CpG}$ islands are often associated with promoter regions or first exons of half the genes in our genome. In normal cells, $80 \%$ of $\mathrm{CpG}$ dinucleotides that are not associated with 
CpG islands (predominantly in intergenic and intronic regions of DNA, repeat sequences and transposable elements) are heavily methylated, whereas $\mathrm{CpG}$ islands are usually unmethylated, whether or not the gene is transcriptionally active [6]. On the contrary, the cancer genome is frequently characterized by both global hypomethylation of intergenic regions resulting in chromosomal instability [5] and specific hypermethylation of $\mathrm{CpG}$ islands in promoters resulting in aberrantly silenced tumor suppressor genes [6].

DNA methylation by itself does not directly repress transcription. The process of silencing needs the involvement of the epigenetic machinery composed of chromatin modifier enzymes, such as histone deacetylases (HDACs) and histone methyltransferases (HMTs), and proteins that are able to read methylation marks, namely the methylCpG binding proteins (MBPs). MBPs recognize methylated DNA and recruit multiprotein complexes containing HDACs that remove acetyl residues from protruding histone tails, hence tightly compacting chromatin and suppressing promoter access to transcription machinery [7].

In the collaboration between the two epigenetic mechanisms that silences gene expression in cancer it is unclear at the moment whether DNA methylation or histone modification is dominant. Studies using drugs that inhibit epigenetic mechanisms showed that HDAC inhibitors alone cannot induce the expression of hypermethylated genes, indicating that DNA methylation may be preponderant. However, in some cases, histone (de)acetylation can drive DNA (de) methylation [8,9], suggesting that DNA methylation may simply be a marker of silent chromatin. Nevertheless, stable gene repression by epigenetics in cancers seems to involve both mechanisms and appears to be a specific mark of cancer cells. The recent discovery of small non-protein-coding RNA, named micro-RNAs (miRNAs), which target 3 -untranslated regions ( $3^{\prime}$-UTR) of genes and repress either their maturation or lead them to their degradation, added a new layer to epigenetic regulation by means of RNA interference [10-12].

As altered patterns of epigenetic modifications are observed in the early stage of carcinogenesis, it was suggested several years ago that aberrant DNA methylation may be used as a biological tool for early detection and prognosis of cancer [13-15]. Moreover, the potential reversibility of epigenetic modifications gives new opportunities for the clinical treatment of cancer [16]. Thus, identifying new pharmacological inhibitors of epigenetic modifications has become the focus of research in many laboratories, and both DNMT and HDAC inhibitors have shown promising results in clinical trials $[17,18]$.

Next to pharmacological inhibitors, growing interest has been shown by researchers in controlling gene expression during the early steps of carcinogenesis and/or using altered pattern of expression of these genes as diagnostic/prognostic markers. Epigenetically marked genes offer great and exciting possibilities in that sense because methylation occurs during the early stages of cancer. Among them, genes encoding secreted and membrane-bound mucins are often aberrantly expressed in tumors and this finding has led to the hypothesis that mucins may be used as diagnostic and/or prognostic factors in epithelial cancers of different origins [19-22]. Alterations of expression include both silencing and overexpression of mucin genes while their promoters share a GC-rich structure and, for most of them, contain a $\mathrm{CpG}$ island [20]. Moreover, the four genes MUC2, MUC5AC, MUC5B and $M U C 6$, encoding the gel-forming mucins, are clustered on the p15.5 region of chromosome 11 (11p15 MUC genes) [23], in an area known to be a hot spot of abnormal methylation in cancer [24]. This explains why most of the studies regarding epigenetic regulation of mucin genes focused on the 11p15 MUC cluster.

In this paper, the studies that were conducted by the authors' laboratory are reviewed, as well as others about the epigenetic regulation of the $11 \mathrm{p} 15$ MUC genes and those about $M U C 1$ and MUC4 genes that encode two membranebound mucins known to participate in tumor progression and alter cancer cell biological properties [25-27]. The second part of the review opens up to the recent development of new technologies to study epigenetic regulation, and the exciting new avenues that mucin gene regulation by miRNAs may provide to the clinicians in terms of therapeutic tools are discussed. No data exist about mucin gene regulation by miRNAs in the literature, so for the first time miRNA databases were searched and the (long) lists of potential regulatory miRNAs targeting $3^{\prime}$-UTRs of mucin genes established. The paper concludes with a discussion of what the detection of mucin gene methylation could bring to the clinician and/or pathologist as a diagnostic/prognostic tool for early detection of cancer and tumor identification/classification.

\section{Mucins and epigenetics}

\subsection{DNA methylation and histone marks}

2.1.1 The $11 p 15$ mucin genes

2.1.1.1 The $11 p 15.5$ chromosomal region

The $11 \mathrm{p} 15$ chromosomal region is of particular interest for studying epigenetic mechanisms of regulation. Aberrant DNA methylation in this region is associated with severe developmental abnormalities [28,29] and cancer [24,30]. This chromosomal region is characterized by one of the highest concentration of $\mathrm{CpG}$ islands in the genome, being separated from each other by $15-100 \mathrm{~kb}$ (Figure 1) [31]. Within this region lies a $1 \mathrm{Mb}$ imprinted domain, containing several genes involved in growth and development, and potential tumor suppressor genes that are aberrantly methylated in cancer [24,32-34]. Interestingly, MUC2, one of the $11 \mathrm{p} 15$ mucins, was recently proposed to have tumor suppressor activity in colorectal cancer [35].

The 11p15 MUC cluster is $400 \mathrm{~kb}$ in length and is situated $\sim 700 \mathrm{~kb}$ from the imprinted domain, between insulin-like growth factor-2 (IGF-2) and Harvey rat sarcoma viral oncogene homolog (H-RAS) genes, within a region containing $15 \mathrm{CpG}$ islands (Figure 1) [23]. Within the cluster, mucin genes are 


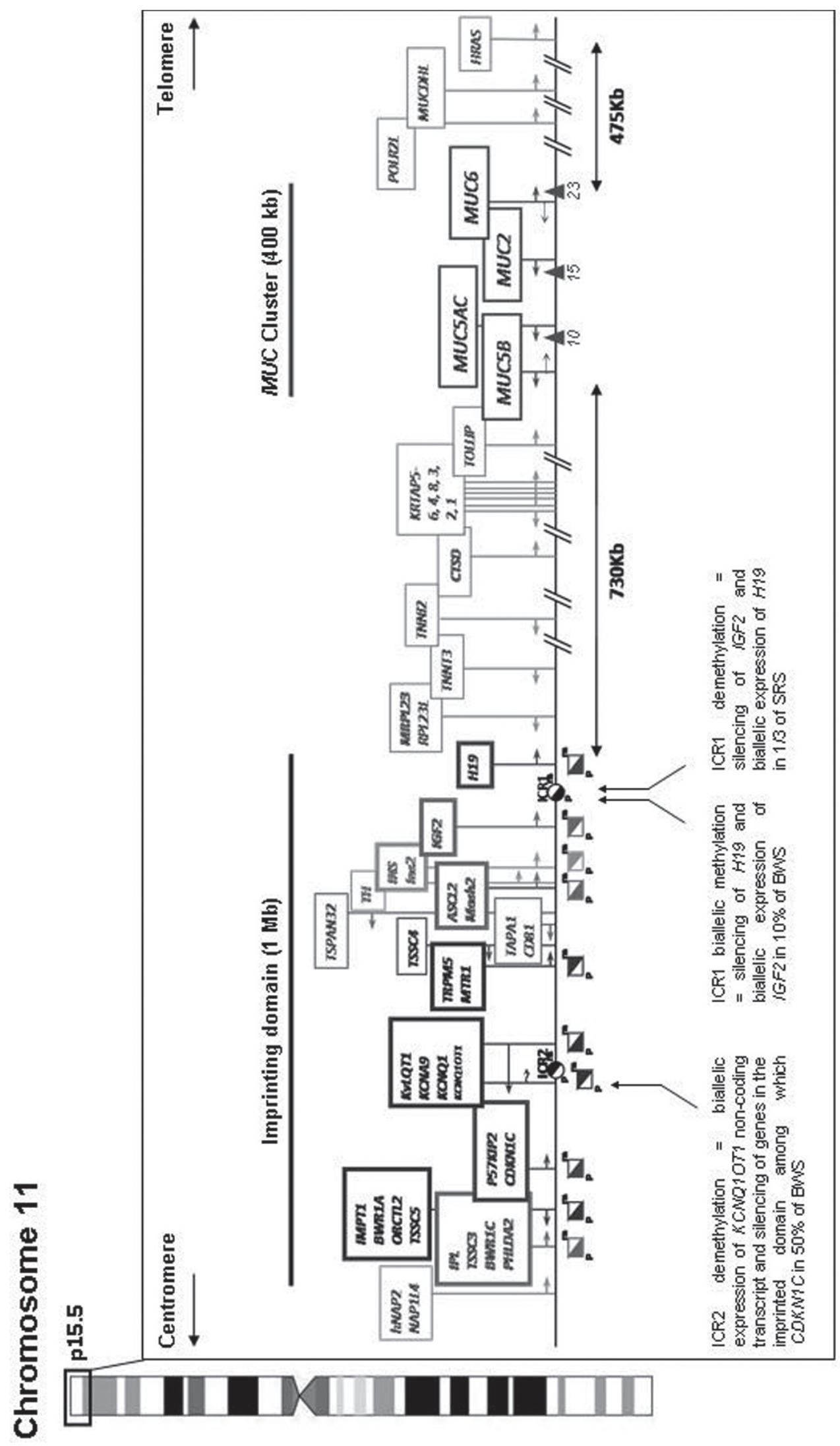


165 organized as follows, MUC6-MUC2-MUC5AC-MUC5B from telomere to centromere, $M U C 2, M U C 5 A C$ and $M U C 5 B$ being transcribed from telomere to centromere, whereas MUC6 is transcribed in the opposite direction (Figure 1).

\section{2.1.1.2 Epigenetic regulation of the 11p15 mucin genes}

The first studies that aimed at studying epigenetic regulation of mucin genes focused on MUC2. Based on the observation that MUC2 mucin expression was repressed in non-mucinous colorectal cancers and their metastasis, Hanski and collaborators

175 were the first to investigate the role of DNA methylation in MUC2 silencing [36]. To this end, they used the methylationsensitive enzyme HpaII and the methylation-independent enzyme MspI to digest DNA from colon carcinoma cell lines expressing variable levels of MUC2, followed by Southern blotting. They showed hypermethylation of MUC2 promoter in non-mucinous carcinoma cell lines [36,37].

Thereafter, arising bisulfite-treated genomic DNA-based methods allowed more precise analysis of methylation profiles of CpG sites involved in MUC2 silencing. These studies 185 showed the involvement of $9 \mathrm{CpG}$ sites situated directly upstream of the transcriptional start site of MUC2, at -289, $-274,-246,-192,-160,-126,-118,-6$ and -2 , in the silencing of the gene in non-expressing normal columnar cells and in the non-mucinous carcinoma tissues of the colon [37] as well

190 as in pancreatic cancer cell lines [38]. The use of methylationsensitive single nucleotide primer extension (Ms-SNuPE) allowed Mesquita and co-workers to demonstrate the role of site-specific promoter hypomethylation in aberrant MUC2 mucin expression in mucinous gastric carcinoma [39].

In 2005, mapping of the methylation status of the $59 \mathrm{CpG}$ sites of MUC2 promoter lying from position -1989 to position +288 in pancreatic cancer cell lines confirmed the role of site-specific methylation in MUC2 silencing, and authors described methylation of DNA binding sites for AP-2 and

200 Sp1 transcription factors. However, the authors did not study the influence of methylation on MUC2 activation by these two transcription factors [40]. They also showed that histone $\mathrm{H} 3$ modification status at MUC2 promoter, and especially demethylation of lysine 4, methylation of lysines 9 and 27 and deacetylation of lysines 9 and 27 , tightly related to DNA methylation, played an important role in MUC2 gene silencing [41].

Very few studies have been conducted concerning the three other genes of the cluster. The first study concerning epigenetic regulation of $M U C 5 B$ was carried out at the authors' laboratory and showed, using HpaII and MspI enzymes combined with Southern blotting and cell treatment with DNA methylation inhibitor 5-aza-22deoxycytidine (5-aza), that the $-1095 /-695$ region of MUC5B proximal

215 promoter was hypermethylated in gastric MUC5B-expressing KATO-III cells, whereas methylation occurred throughout the 55-flanking region in gastric low-expressing AGS cells $[20,42]$. This pattern of methylation corresponded to the downregulation of MUC5B apomucin expression observed in undifferentiated gastric carcinomas [42]. The only study carried out on MUC5AC and more particularly on one $\mathrm{CpG}$ site in pancreatic cancer cell lines did not show any correlation between epigenetic regulation of the gene and expression of the apomucin [43].

To assess whether epigenetic regulation of the four 11p15 MUC genes was concerted and associated with cancer, a simultaneous study was undertaken of the four genes in a wide panel of human epithelial cancer cell lines with different epithelial origins and different status of differentiation [44]. The analysis was carried out on large portions of the promoters, that is, 230 $3.3 \mathrm{~kb}$ for MUC2, $1.3 \mathrm{~kb}$ for $M U C 5 A C, 2.3 \mathrm{~kb}$ for $M U C 5 B$ and $1.8 \mathrm{~kb}$ for MUC6. In silico analysis showed that MUC2, MUC5B and MUC6 promoters were particularly rich in $\mathrm{G}+\mathrm{C}$ nucleotides, up to 70,80 and $75 \%$, respectively, and contained CpG islands of 115, 104 and 166 bp in length, respectively, situated at $-4647 /-4533,-976 /-873$ and $-160 /+6$, whereas relatively few $\mathrm{CpG}$ sites were found in MUC5AC [44].

The studies indicate that regulation by methylation (after treatment with 5-aza) and by histone acetylation (after treatment with HDAC inhibitor trichostatin A [TSA]) is both gene- and cell-specific. In some cases, TSA induced repression of mucin gene expression, especially in confluent differentiated cells expressing high levels of the mucin gene of interest [44]. The same inhibitory mechanism by the HDAC inhibitor sodium butyrate had previously been found in MUC2 high-expressing intestinal cancer cell lines [45]. This may reflect a mechanism of definitive function of the secretory lineage in order to maintain epithelial homeostasis [46].

Bisulfite-treated genomic DNA sequencing and chromatin immunoprecipitation (ChIP) assays confirmed that MUC2 was regulated by site-specific DNA methylation associated with establishment of a repressive histone code, including histone $\mathrm{H} 3$ deacetylation and methylation of lysine 9. Moreover, our study covering the $-3269 /-1791$ region of $M U C 2$ promoter allowed us to identify 4 more relevant CpG sites at -3269 , $-3199,-2331$ and -1912 . It was also shown that hypermethylation of MUC5B promoter was the main mechanism responsible for its silencing in epithelial cancer cells and involved a wide region of its distal promoter at $-2677 /-2163$, as well as cytosines at -434 and -421 in the proximal promoter. Thus, we and others have identified key methylated cytosines in MUC2 and MUC5B promoters that should provide useful tools, which are easy to detect, to screen mucin gene repression by methylation in epithelial cancers and identify tumors in which their repression may indicate good or poor prognosis.

On the contrary, the expression of $M U C 5 A C$ was rarely influenced by epigenetic mechanisms and it was not possible to identify $\mathrm{CpG}$ sites in its promoter which hypermethylation would be associated with its silencing. Hypermethylation of MUC6 promoter was not correlated to its repression because DNMT and HDAC inhibitors had no influence on its expression in the cancer cell lines studied. Thus, epigenetic 
regulation of $11 \mathrm{p} 15$ MUC genes is not concerted and involves gene-specific mechanisms [44].

Interestingly, our study also indicates that $11 \mathrm{p} 15$ mucin genes share a common feature regarding the methylation pattern of their promoters, which is that their CpG islands are heavily methylated regardless of their level of expression in the cancer cells studied [44]. However, these results will have to be confirmed in normal tissues compared with tumors because it is known that cancer cell lines often harbor an altered methylation pattern of their genome and excessive CpG island hypermethylation [47].

DNMT1, by a small interfering RNA (siRNA) approach, was identified as a potent regulator of MUC2 and MUC5B epigenetic regulation. The DNMT1 effect was potentiated by HDAC2. In the same studies it was found that methylation of the two promoters dramatically impaired their activation by $S p 1$ transcription factor. Finally, one of the most important findings in this study was that MUC2 and MUC5B epigenetic regulation, and particularly the methylation profile of their promoters, was directly dependent on the cell differentiation 295 status, leading to the hypothesis that hypermethylation of MUC2 and MUC5B may be a specific mechanism used by epithelial cancer cells to maintain a proliferating undifferentiated state or by normal cells to maintain pluripotency during development [44].

\subsubsection{Membrane-bound mucins}

\subsubsection{MUC4}

The 5'-flanking region of MUC4 is characterized by a high $\mathrm{G}+\mathrm{C}$ content, up to $72 \%$ concentrated almost exclusively in the proximal promoter and the $5^{\prime}$-UTR, and the presence of two CpG islands of 135 and $146 \mathrm{bp}$, respectively, both located in the proximal promoter at $-2370 /-2236$ and $-738 /-593$ [48].

The influence of histone deacetylation on MUC4 silencing was first assessed by the authors' laboratory in the pancreatic cancer cell line PANC-1 using cell treatment with TSA [49] and later shown in prostate cancer cells treated with sodium butyrate by Singh and co-workers [50]. This group also showed the influence of DNA methylation in regulating MUC4 in these cells by using 5-aza.

315 The studies in epithelial cancer cells that express variable levels of MUC4 showed that MUC4 proximal and distal promoters, including both $\mathrm{CpG}$ islands, were heavily methylated whether or not the gene was expressed in the cells. On the contrary, MUC4 5'-UTR, and particularly cytosines at $-81,-93,-102,-113$ and -121 , showed a methylation profile that was directly correlated to the level of MUC4 expression in the cells [48]. Hypermethylation of MUC4 5'-UTR was associated with the establishment of a repressive histone code, including deacetylation of histone $\mathrm{H} 3$ and methylation of lysines 9 and 27 of histone H3 [48]. As four Sp1 binding sites had previously been identified and located, just upstream of and within the 5'-UTR [51], the influence of methylation of these Sp1 cis-elements on the regulation of MUC4 by this transcription factor after in vitro methylation of the promoter coupled to site-directed mutagenesis of the Sp1 sites was investigated further. It was found that methylation of Sp1 binding sites located in the proximal promoter and the $5^{\prime}$-UTR at $-276 /-271$ and $-166 /-156$ dramatically impaired MUC4 activation by Sp1, whereas methylation of the adjacent $\mathrm{CpG}$ site upstream of the 5'-UTR had no effect. Finally, siRNA approach and ChIP assays allowed us to identify DNMT3A, DNMT3B and HDAC3 as potent regulators of MUC4 endogenous expression that directly bind to its $5^{\prime}$-UTR [48].

From these results, a model was proposed of MUC4 340 epigenetic regulation in epithelial cells [48]. In normal pancreatic cells that do not express MUC4 [52], MUC4 silencing would be mediated by DNA methylation and histone deacetylation at the 5'-UTR, whereas in early steps of pancreatic carcinogenesis progressive demethylation would allow low expression of MUC4, and finally in adenocarcinomatous high-expressing cells, selective hypomethylation and permissive chromatin would allow binding of essential transcription factors such as Sp1 and full transcription of the MUC4 gene. Recently, Yamada and co-workers showed that the methylation level of cytosines at -170 and -160 was associated with MUC4 gene expression in 10 cancer cell lines using the MassARRAY compact system, and therefore confirmed the critical contribution of promoter $\mathrm{CpG}$ methylation in MUC4 silencing [53].

2.1.2.2 MUC1

The $M U C 1$ gene is characterized by the presence of a $\mathrm{CpG}$ island in a large transcribed region that consists of 60-bp tandemly repeated units, each containing $1 \mathrm{SmaI}$ restriction site. The first evaluation of the methylation status of various regions of the MUC1 gene by Zrihan-Licht and co-workers using the methylation-sensitive enzymes SmaI and XmaI showed that, in peripheral blood leukocytes that do not express $M U C 1$, the 60-bp repeat array was completely methylated, whereas the same sequences were entirely unmethylated in DNA from MUC1-overexpressing breast tumor tissue. Hypomethylation within the repeat array was also observed in other epithelial tissues that express $M U C 1$ at much lower levels than those seen in breast cancer tissue, demonstrating that hypomethylation of the tandem repeat array was an absolute requirement for $M U C 1$ gene expression in epithelial tissues [54]. The influence of epigenetics in $M U C 1$ silencing was then confirmed in prostate cancer cells by using cell treatment with 5-aza and sodium butyrate [50]. The precise mechanisms of epigenetic regulation at MUC1 promoter had not been deciphered until recently, when Yamada and co-workers found hypermethylation of cytosines at $-70,-55,-51,-47,-31,-21,-14,-4$ and +20 , tightly associated with dimethylation of $\mathrm{H} 3-\mathrm{K} 9$, in most MUC1 non-expressing cell lines, providing the first proof that $M U C 1$ gene expression was regulated by DNA methylation of the promoter and associated histone $\mathrm{H} 3$ lysine 9 (H3-K9) modification [55]. 


\subsection{Moving towards using mucin methylation as a diagnostic tool}

Bisulfite-treated DNA sequencing of single clones is a gold standard and has been a very useful tool in our comprehensive studies to analyse precisely the methylation profile of mucin gene promoters and to determine the key $\mathrm{CpG}$ sites to use mucin gene methylation as a biomarker. However, application of this method in routine procedures for molecular diagnosis is constrained by several issues, as it is complex, time-consuming, expensive, and requires a fair number of sequenced clones to be considered quantitative. Therefore, our laboratory is currently validating the pyrosequencing technology to analyse the methylation status of mucin promoters in human tissues and validate the use of mucin gene methylation as a diagnostic and/or prognostic tool in epithelial cancers. Pyrosequencing is a fast, robust and flexible sequencing-by-synthesis-based method that offers a reproducible quantification of individual, consecutive $\mathrm{CpG}$ sites (up to $100 \mathrm{bp}$ amplicon length), enabling discrimination of small changes in methylation levels, from single cytosines to global methylation of a promoter region, in a large number of samples [56].

This switch to pyrosequencing seems very promising, as our first data for $M U C 5 B$ (this review), $M U C 5 A C$ and MUC4 (unpublished data) already allowed us to confirm the potent status of $\mathrm{CpG}$ methylation as a biological tool in lung, colon and pancreatic cancer, respectively. The high level of methylation of $M U C 5 B$ distal promoter seen in a MUC5B non-expressing normal lung tissue by bisulfite DNA sequencing is even more important in the corresponding MUC5B non-expressing lung adenocarcinoma (Figure 2A). In another histologic type of lung cancer, a MUC5B nonexpressing squamous cell lung carcinoma, it was also found, using pyrosequencing, that $M U C 5 B$ distal promoter was hypermethylated at cytosines $-2430,-2424$, and -2421 when

420 compared with normal lung tissue (Figure 2B). Regarding MUC4, our first analysis of its pattern of methylation in normal and cancerous pancreatic tissues confirmed that demethylation of cytosines at $-93,-102$ and -113 occurs in pancreatic adenocarcinoma when compared with MUC4-non-expressing normal pancreas (not shown). Although these preliminary data need further confirmation on larger panels of tissues, it is hoped to provide a rapid way of evaluating mucin gene methylation in cohorts and use it as a specific biomarker. As mucin genes show altered expression in various types of epithelial cancer (adenocarcinoma, squamous carcinoma), and also in numerous organs, tissues (respiratory tract, gastrointestinal tract, urogenital tract, etc.) and fluids (tears, saliva, sperm, milk, etc.), a lot of work as yet to be done. Moreover, in the future this method should be of great help to determine the prevalence of mucin gene methylation in genomic DNA released from tumors in biological fluids such as plasma or serum, bronchoalveolar lavages for lung cancer, and pancreatic juice for pancreatic cancer.

\subsection{Mucins and epigenomics}

All the techniques that were used to study epigenetic changes at promoters of candidate genes can now be coupled both with genome-wide approaches, such as microarray technologies, and high-throughput methods, such as ultradeep sequencing, for high-resolution mapping of epigenetic profiles in both normal and cancer cell types [57,58]. Methods for genome-wide mapping of DNA methylation patterns include methylated CpG island amplification (MCA), followed by hybridization on microarrays [59], methylated DNA immunoprecipitation (MeDIP)-on-chip [60], or ultradeep bisulfite sequencing [61]. Similarly, histone modification status can be widely studied using chromatin-immunoprecipitation-based methods [13,62] such as ChIP-on-chip or ChIP-seq. These new technologies will allow us to decipher further the mechanisms by which mucin genes are epigenetically regulated as clusters. Indeed, regulation of the 11p15 MUC cluster at the gene level has been studied previously in the authors' laboratory, but has not yet been completely understood at a more global level. Similarly, regulation of mucin gene clusters at 3q29 (MUC4, MUC20) and 7q22 (MUC3, MUC12, MUC17) chromosomal regions [26] remains to be investigated.

These genome-wide approaches will also be essential and necessary if one wants to give an explanation of the neveranswered hypothesis as to how the tight coordination works and leads to simultaneous expression of a specific panel of both secreted and membrane-bound mucins, which follow two different biosynthetic pathways, in each type of epithelium. Finally, these comprehensive studies will allow us to understand better the specific mechanisms responsible for maintaining epithelium protection, as mucins are key proteins in epithelial homeostasis, and, therefore, the potential impacts of the dysregulation of their genes in epithelial diseases.

Most importantly, as it is now agreed that individual biomarkers are not informative enough for the diagnosis of most tumor types, translational epigenomics will be an essential tool to determine an ideal set of various biomarkers (tumor ID or tumor signature), which will include specific epigenetic modifications of mucin genes, that may define each neoplasia and therefore be used for diagnosis and prognosis of epithelial cancers.

\subsection{Mucins and regulating RNAs 2.4.1 MicroRNAs}

MicroRNAs are endogenous non-coding RNAs, of $18-24$ nucleotides in length, typically excised from 60 to 110 nucleotide foldback RNA precursor structures [63], that play important negative regulatory roles in animals and plants by targeting messenger RNA transcripts for degradation or translational repression, involving the RNA interference silencing complex (RISC) [10]. Recently, Gonzalez and co-workers showed that miRNAs can also trigger transcriptional silencing by means of chromatin remodelling (i.e., trimethylation of $\mathrm{H} 3 \mathrm{~K} 9)$ at DNA regions containing complementary sequences [64]. 
A.

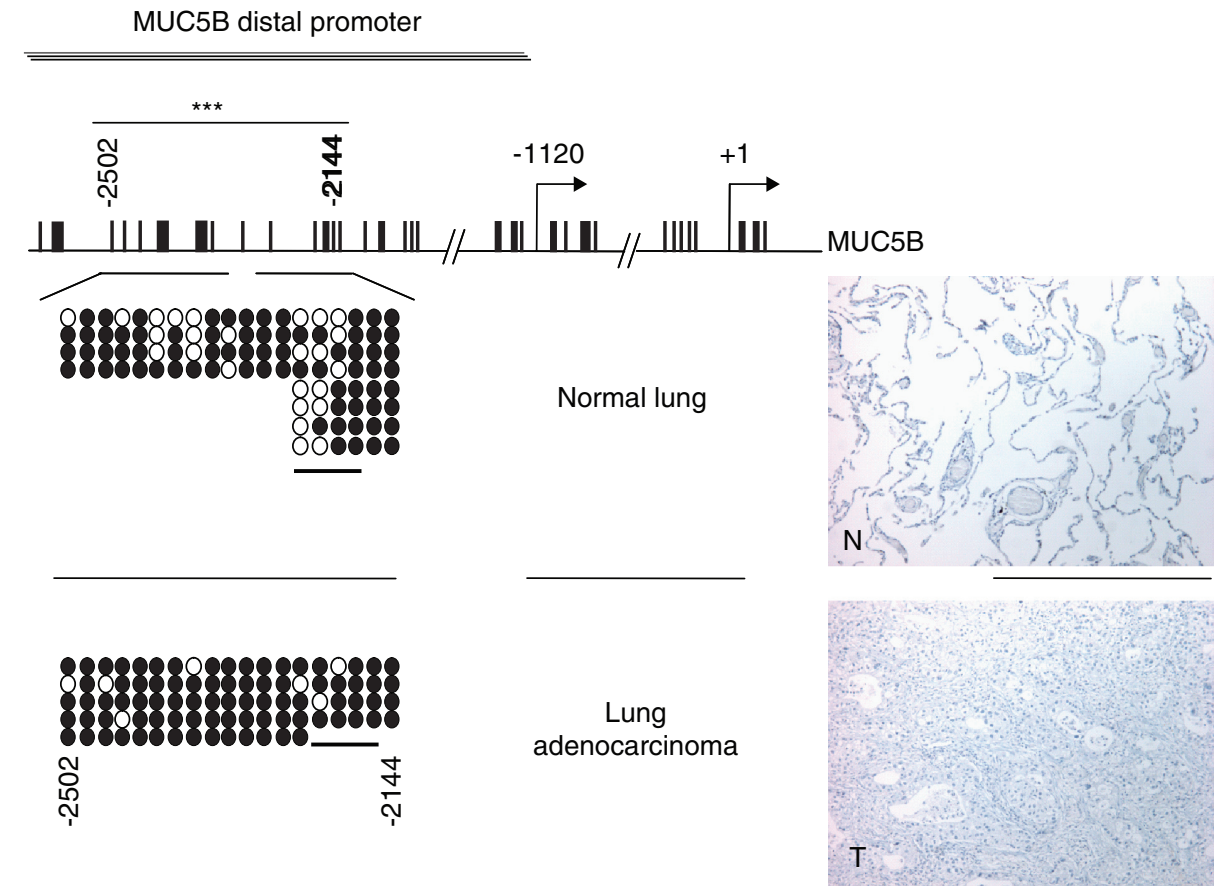

B.
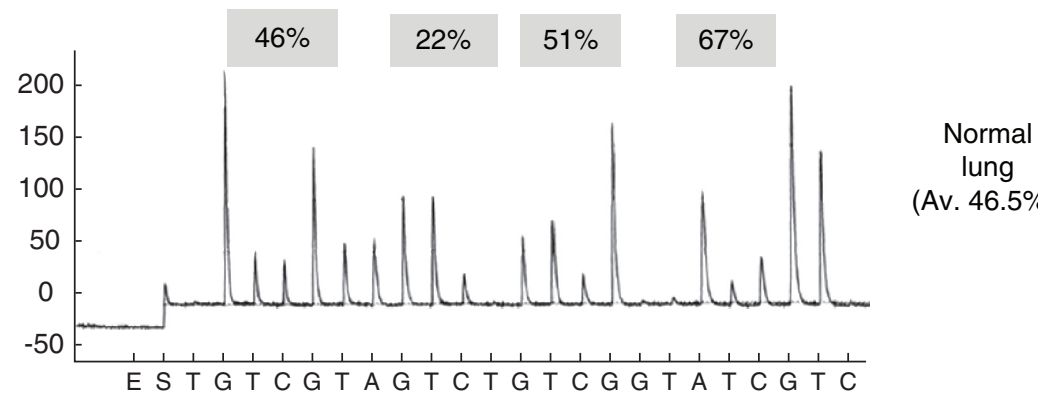

(Av. 46.5\%)
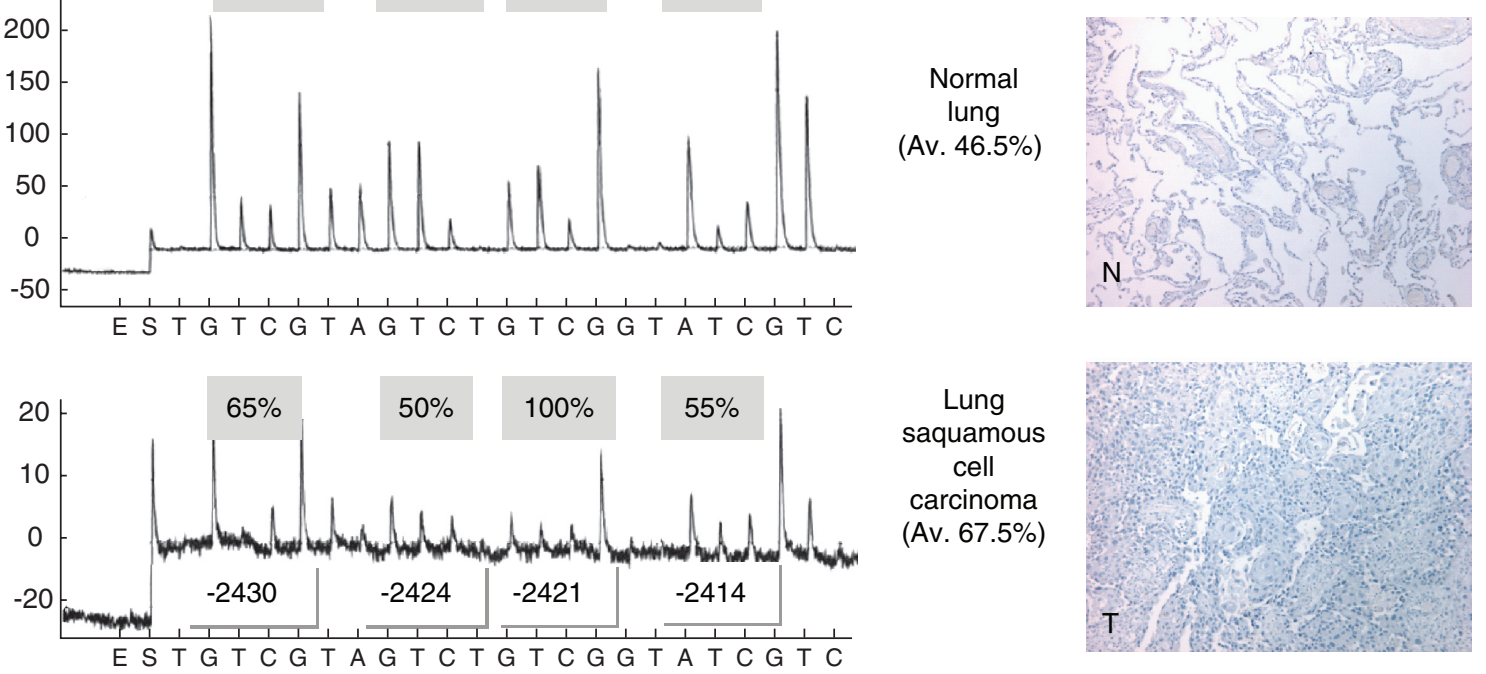

Figure 2. Methylation profile of MUC5B distal promoter in MUC5B non-expressing lung cancers. A. Mapping of methylated cytosines was carried out by bisulfite-treated DNA sequencing in normal lung (upper panel, N) and in a MUC5B-negative lung adenocarcinoma (lower panel, T). On the right-hand side is shown immunohistochemical staining of MUC5B apomucin in the corresponding tissues (magnification $\times 100$ ). Partial sequence of $M U C 5 B$ promoter is represented by the horizontal bar. Numbering refers to the proximal transcription start site of $\operatorname{MUC5B}(+1$, broken arrow) $[42,106]$. Vertical bars indicate $C p G$ sites. More than four individual clones were analysed per CpG site and type of tissue (normal lung or lung adenocarcinoma). Black circles represent methylated cytosines and open circles represent unmethylated cytosines. Key CpG methylated sites previously identified in cancer cell lines [44] are topped with a star and their position in the promoter is indicated. The horizontal thick bar indicates the promoter region analysed further using the pyrosequencing technology. B. Mapping of methylated cytosines in MUC5B promoter by pyrosequencing in normal lung (upper panel, $\mathrm{N}$ ) and in a MUC5B-negative lung squamous cell carcinoma (lower panel, T). On the right-hand side is shown immunohistochemical staining of MUC5B apomucin in the corresponding tissues (magnification $\times 100$ ). The pyrograms show the methylation percentages of the four CpG sites of interest $(-2430,-2424,-2421$ and -2414$)$ in MUC5B distal promoter using the pyrosequencing technology (PyroMark ${ }^{\mathrm{TM}}$ MD, Biotage).

Av: The average methylation content of the promoter in normal lung compared with lung squamous cell carcinoma. 
So far, hundreds of unique, mature miRNAs have been identified in humans, with more to be discovered. Their expression levels vary greatly among tissues [65] and especially during pathological processes [66], including carcinogenesis [12,67,68]. Chromosomal rearrangements, genomic amplifications or deletions, epigenetic regulation and mutations at genes encoding miRNAs lead to their specific overexpression or underexpression in different types of tumor, which contributes to cancer development and progression. Changes in miRNA expression have been reported by various genome-wide tech505 niques (microarray platforms, bead-based flow cytometry) in colorectal neoplasia [69], pancreatic cancer [70-72], kidney and bladder cancers [73], esophageal [74] and gastric carcinomas [75] and lung cancer [76], potentially affecting expression levels of numerous putative targets (Table 1). This led to the new concept of miRNA expression signatures [75] associated with cancer diagnosis (tissue type), predisposition, prognosis (differentiation and aggressiveness, [77]), identification of a primary tumor [78] and response to therapy [79]. Moreover, miRNAs are present in human plasma in a remarkably stable form and therefore 515 represent a potentially useful approach for the biological fluid-based detection of human cancer [80]. For most miRNAs though, identification of their target genes and the biological consequences of their repressive activity on cancer progression remain to be defined.

No evidence for mucin gene regulation by miRNAs has been reported so far. However, interrogation of MiRbase and MiRanda databases ([81-84]) revealed a large number of miRNAs that could potentially target 33-UTR of mucin genes encoding either the membrane-bound mucins MUC1, MUC4, MUC20, MUC3A/3B, MUC17 and MUC13 or the secreted mucins MUC2, MUC5AC, MUC6, MUC7 and MUC19 (Table 2). Interestingly, although miRNAs might be responsible for mucin gene regulation, a recent study by Ramasamy and co-workers showed, conversely, that $530 \mathrm{~N}$-glycosylation of Asn-36 on MUC1 C-terminal subunit suppresses miR-322 expression in breast and prostate cancer cells, thereby increasing expression of galectin-3 [85]. This very interesting result suggests that, in turn, mucins may regulate miRNA expression and activity.

\subsubsection{Antisense RNA}

Natural antisense transcripts are endogenous RNA molecules containing sequences that are complementary to the proteinencoding sense transcript. Cis antisense RNAs are transcribed

540 at the same genomic locus from the opposite strand, whereas trans antisense RNA are transcribed from separate loci. Antisense RNAs are thought to regulate their target genes at the genomic level by triggering chromatin remodelling [86], or at the transcriptomic level by interfering with mRNA transcription, processing, stability, translocation and translation [87].

Recently, evidence for antisense transcripts has been reported in $2900-6400$ human genes using the asymmetric strand-specific analysis of gene expression (ASSAGE) technology [88]. The distribution of these antisense RNAs is non-random across the genome and differs among cell types, suggesting a fundamental role in regulation of sense transcription. In this comprehensive study, sense and antisense expression of 32,354 Ensembl genes in three cancerous and two normal cell lines was assessed, including those of MUC1, MUC4, MUC3A/3B, MUC17, MUC16, MUC2, MUC5AC, $M U C 5 B, M U C 6$ and $M U C 7$. The results show that high expression of $M U C 5 B$ and $M U C 6$ antisense RNAs (Figure 1) was found in non-epithelial cells that do not express sense transcripts of these genes. These preliminary data concerning expression of mucin antisense RNAs will need further investigation. Moreover, as epigenetic silencing of tumor suppressor genes by their antisense RNA has already been reported, the role of these transcripts in mucin gene silencing by methylation and histone modifications will have to be elucidated.

\section{Expert opinion}

It is obvious that epigenetic regulation of mucin genes is still at its dawn, but in vitro studies in cancer cell lines, expression studies on human tissue sections and very recent genome-wide studies using new technologies clearly indicate that DNA methylation of their promoters is a key molecular mechanism regulating their expression in epithelial cancers. Detection of MUC methylation may thus soon provide a useful biological tool for the clinician. The greatest challenge for researchers working in the mucin field is of course related to the huge diversity of these glycoproteins and also their genes ( $>20$ known until now), the huge size of the genes, their polymorphisms, and the redundancy that such a complex family of molecules may create.

We think that systematic comparison of MUC methylation in normal and carcinomatous tissues will provide useful tools for diagnosis and prognosis of numerous epithelial cancers, including those of lung [89], pancreas [90] and colon [91], but also esophageal and gastric carcinoma. Alterations in DNA methylation are early events in carcinogenesis and, as such, could become specific and sensitive biomarkers that could be detected in biological fluids such as blood (liver cancer), sputum and bronchoalveolar lavage (lung cancer), feces (colon cancer), urine (bladder cancer) or nipple aspirate (breast cancer) [5,92]. However, so far, methylation status for one particular gene as a reliable marker has been described only in rare cases (GSTP1 in prostate cancer [93] or APC in esophageal adenocarcinoma [94]). Most of the time, analysis of several genes (methylome signature) is necessary to distinguish cancers from normal tissues or other pathologies [88,95]. Moreover, as methylation is a tumor-specific change in DNA, identification of panels of complementary biomarkers may help to classify histopathologic tumor types, tumor grades as well as tumors from different tissues [13]. Thus, methylation of genes encoding mucins, which are markers of cell differentiation in many epithelial tissues, may provide a very useful tool to clinicians and pathologists. 
Table 1. Putative target genes of differentially expressed miRNAs identified in aerodigestive cancers.

\begin{tabular}{|c|c|c|c|}
\hline MiRNA & $\begin{array}{l}\text { Chromosomal } \\
\text { localization }\end{array}$ & Putative targets & Tumor type \\
\hline let-7 family & Multiple loci & $\begin{array}{l}\text { Ras }^{\ddagger}, c-m y c^{\ddagger}, \text { HMGA2, IMP-1, } \\
\text { ARID3B, HIC2, GM632 }\end{array}$ & Kidney, colon, lung ${ }^{\S}$ \\
\hline miR-100 & $11 q 24.1$ & $\begin{array}{l}\text { FZD8, INSM1, SMARCA5, ZZEF1, } \\
\text { FRAP1, TRIB2, HOXA1, FGF3 }\end{array}$ & Esophagus \\
\hline miR-103-1 & $5 q 35.1$ & $\begin{array}{l}\text { RAB10, ZHX1, OGT, HSHIN1, } \\
\text { BACH2 }\end{array}$ & Bladder \\
\hline miR-106a & $X q 26.2$ & $\begin{array}{l}\text { MAP3K9, MAP3K11, MAPK9, } \\
\text { FASTK, ARHGAP12, BCL2L11 }\end{array}$ & Colon, pancreas \\
\hline miR-107 & $10 q 23.31$ & FGFR2, CCNE1, MAP2K3 & $\begin{array}{l}\text { Colon, pancreas, } \\
\text { stomach }\end{array}$ \\
\hline miR-125b & $11 q 24.1$ & $\begin{array}{l}\text { BAK1, MIZF, MAP2K7, RAB6B, } \\
\text { MMP11, MADD }\end{array}$ & Esophagus \\
\hline miR-143 & $5 q 32-33$ & MAPK $7^{\ddagger}$, MAP3K7, KRAS, HOXA5 & Colon \\
\hline miR-146a & $5 q 33.3$ & IRAK1 & Pancreas \\
\hline miR-152 & $17 q 21.32$ & ELF5, TGIF2, DNMT1, CDC2L5 & Esophagus \\
\hline miR-155 & $21 \mathrm{q} 21.3$ & PLR3 $^{\ddagger}$, FGF7, GDF6, TP53INP1 & Colon, lung $\$$, stomach \\
\hline miR-17-5p & $13 q 31$ & $\begin{array}{l}\text { ZBTB4, ITGB8, EZH1, KIAA1404, } \\
\text { GM632 }\end{array}$ & $\begin{array}{l}\text { Bladder, colon, lung, } \\
\text { pancreas }\end{array}$ \\
\hline miR-181b-1 & $1 q 31.3$ & $\begin{array}{l}\text { ADARB1 CTDSPL PAWR PHF15 } \\
\text { TNFSF11 }\end{array}$ & Pancreas \\
\hline miR-185 & $22 q 11.2$ & $\begin{array}{l}\text { ZNFN1A4, SLC16A2, PCDHAC2, } \\
\text { PCDHAC1, PCDHA8 }\end{array}$ & Kidney, bladder \\
\hline miR-191 & $3 p 21.31$ & $\begin{array}{l}\text { GAP43, EGR1, MAP3K12, NRCAM, } \\
\text { CCND2, FZD5, PLCD1 }\end{array}$ & $\begin{array}{l}\text { Colon, lung, pancreas, } \\
\text { stomach }\end{array}$ \\
\hline miR-192 & $11 q 13.1$ & ATF1, CCNT2, RAB2 & Esophagus \\
\hline miR-194 & $1 q 41$ & CROP, TGIF1 & Esophagus \\
\hline miR-200c & $12 p 13.31$ & RELN, PDCD10, PCDH8 & Esophagus \\
\hline miR-203 & $14 q 32.33$ & $\begin{array}{l}\text { ZNF281, RKHD2, MGC39518, } \\
\text { TRPS1, LPIN1 }\end{array}$ & Bladder, esophagus \\
\hline miR-205 & $1 q 32.2$ & $\begin{array}{l}\text { PLCB1, CPEB2, MGRN1, ESRRG, } \\
\text { CHN1 }\end{array}$ & Bladder, esophagus \\
\hline miR-21 & $17 q 23.1$ & $\begin{array}{l}\text { BCL2, NTF3, PDCD4, RAB6A, } \\
\text { RAB6C, RASA1, RHOB, SKI, TGFBI, } \\
\text { TGFBR2, TIMP3 }\end{array}$ & $\begin{array}{l}\text { Colon, lung, } \\
\text { pancreas }^{\S}, \\
\text { stomach, esophagus }\end{array}$ \\
\hline miR-214 & $1 q 24.3$ & FGFR2, IGF1R, RAB14, RAB15 & Pancreas, stomach \\
\hline miR-221 & Xp11.3 & $\begin{array}{l}\text { RIMS3, HECTD2, CDKN1B, } \\
\text { RBM24, ZFPM2 }\end{array}$ & $\begin{array}{l}\text { Bladder, colon, } \\
\text { pancreas, stomach }\end{array}$ \\
\hline miR-223 & $X q 12-13.3$ & $\begin{array}{l}\text { MEF2C, ZCCHC14, UE2A, } \\
\text { SPRED1, SACS }\end{array}$ & $\begin{array}{l}\text { Bladder, colon, } \\
\text { pancreas, stomach }\end{array}$ \\
\hline miR-23a & 19p13.2 & $\begin{array}{l}\text { CCNT2, TOP1, SATB1, } \\
\text { SEMA6D, NEK6 }\end{array}$ & Bladder \\
\hline miR-23b & $9 q 22.31$ & $\begin{array}{l}\text { CCNT2, TOP1, SATB1, } \\
\text { SEMA6D, NEK6 }\end{array}$ & Bladder \\
\hline
\end{tabular}

FIdentified targets.

\$Prognostic and/or diagnostic markers.

Adapted from Gottardo et al. [73], Volinia et al. [75], Feber et al. [74] and Calin and Croce [63].

Target prediction is based on miRBase, TargetScan and MiRanda. The listed miRNAs are predicted by at least two of these prediction programs The most likely tumor-related genes are listed. 
Table 1. Putative target genes of differentially expressed miRNAs identified in aerodigestive cancers (continued).

\begin{tabular}{|c|c|c|c|}
\hline MiRNA & $\begin{array}{l}\text { Chromosomal } \\
\text { localization }\end{array}$ & Putative targets & Tumor type \\
\hline miR-24-1 & $9 q 22.32$ & $\begin{array}{l}\text { BCL2L11, TRAF7, CREBL2, IGFBP5, } \\
\text { PCDH10, TP53INP1, RASA1, MAPK7 }\end{array}$ & $\begin{array}{l}\text { Colon, pancreas, } \\
\text { stomach }\end{array}$ \\
\hline $\operatorname{miR}-25$ & $7 q 22.1$ & $\begin{array}{l}\text { PCDH11X, RAB23, FZD10, } \\
\text { CDH10, E2F3 }\end{array}$ & Pancreas, stomach \\
\hline miR-26b & $2 q 35$ & $\begin{array}{l}\text { NHS, HSHIN1, LARP1, LOC153222, } \\
\text { DDX3X }\end{array}$ & Bladder \\
\hline miR-28 & $3 q 28$ & SSRP1, SFRS5, RHO, GPM6A, EN2 & Kidney \\
\hline miR-29b-2 & $1 q 32.2$ & $\begin{array}{l}\text { COL3A1, COL4A1, COL4A5, } \\
\text { COL7A1, COL2A1, COL15A1, } \\
\text { TFAP2C, CCNYL1, NKRF }\end{array}$ & colon, pancreas \\
\hline miR-30c & $1 p 34.2$ & PCDH10 & Colon, pancreas \\
\hline miR-32 & $9 q 31.3$ & $\begin{array}{l}\text { RAB14, RAB23, RAP1B, CREM, } \\
\text { MYCBP2, FZD10, CREB1, SMAD7, } \\
\text { NOTCH1, PAX3, SMAD6, GAP43 }\end{array}$ & Colon, pancreas \\
\hline miR-7-2 & $15 q 25$ & $\begin{array}{l}\text { SPATA2, OGT, POLE4, RSBN1, } \\
\text { KIAA1920 }\end{array}$ & Kidney \\
\hline miR-93 & $7 q 22.1$ & CREBL1, MYCN, MAPK9 & Esophagus \\
\hline
\end{tabular}

${ }^{\ddagger}$ Identified targets.

§Prognostic and/or diagnostic markers.

Adapted from Gottardo et al. [73], Volinia et al. [75], Feber et al. [74] and Calin and Croce [63].

Target prediction is based on miRBase, TargetScan and MiRanda. The listed miRNAs are predicted by at least two of these prediction programs The most likely tumor-related genes are listed.

Yet, this potential future promising clinical application depends crucially on the discovery of useful aberrantly methylated sequences. In this context, studying the methylation status of mucin genes, which are aberrantly expressed in cancers, may help to develop these early detection tools. The development of new powerful, reliable and rapid methods, such as pyrosequencing or high-throughput technologies on chips $[13,96]$, to screen methylated genes in tissues should quickly provide new information regarding mucin gene epigenetic status in tissues from cancer patients and at different stages of carcinogenesis.

The studies of epigenetic regulation of mucin genes also point out the opposite role of secreted and membrane-bound mucins in carcinogenesis. Indeed, genes encoding secreted mucins, and especially MUC2 and MUC5B, are often 620 aberrantly silenced in non-mucinous colon [97] and lung [98] carcinomas, respectively, whereas genes encoding MUC1 and MUC4 membrane-bound mucins are overexpressed in cancers particularly in breast [99] and pancreatic [100] carcinomas, respectively. Moreover, in cancers, expression of secreted mucins is often associated with better prognosis [101], whereas expression of membrane-bound mucins is associated with tumor cell detachment, invasion and metastasis and worse prognosis [99,102]. These data are in accordance with the findings that MUC2 and MUC5B promoters are hypermethylated, whereas those of MUC1 and MUC4 are demethylated in cancers. Aberrant silencing of specific genes by hypermethylation and ectopic onco-fetal expression of other genes by demethylation are common features of cancer cells and lead to selective advantage in term of growth and survival. Thus, epigenetics provide a new generation of tumor suppressor genes and oncogenes [103]. Therefore, studying epigenetic regulation of mucin genes may help clarify their role in carcinogenesis as candidate tumor suppressor genes, as has already been suggested for Muc2 [35], or oncogenes, as has already been proposed for 640 MUC1 [104].

Finally, the findings that mucin genes may be epigenetically regulated in cancers prompt us to consider them as attractive targets for new therapeutic strategies. As epigenetic changes are potentially reversible, an increasing number of specific DNA methylation or histone deacetylation pharmacological inhibitors have been developed over the past few years. Among them, the DNMT inhibitor 5-aza (decitabine) is the most extensively studied and has been shown to reactivate MUC2 and MUC5B in vitro in numerous cancer cell lines [44]. On the other hand, the HDAC inhibitor TSA, which is known to induce apoptosis and enhance the response to chemotherapeutic agents in pancreatic cancer [105], has been shown to induce a severe decrease of MUC4 expression in pancreatic cancer cells [48]. Hence, in the future, potential application of epigenetic drugs in either reactivating expression of secreted mucins or inhibiting membrane-bound mucins will have to be investigated. 
Table 2. Predicted miRNA targeting mucin genes.

\begin{tabular}{|c|c|c|c|}
\hline Mucin gene & Chromosomal localization & Number of predicted miRNA & List of iRNA \\
\hline \multicolumn{4}{|c|}{ Membrane-bound mucins } \\
\hline MUC1 & $1 q 21$ & 27 & $\begin{array}{l}\text { miR-183 } \\
\text { miR-193b } \\
\text { miR-219-2-3p } \\
\text { miR-296-5p } \\
\text { miR-320 } \\
\text { miR-328 } \\
\text { miR-331-5p } \\
\text { miR-367 } \\
\text { miR-371-5p } \\
\text { miR-485-5p } \\
\text { miR-502-5p } \\
\text { miR-509-3p } \\
\text { miR-512-5p } \\
\text { miR-519e } \\
\text { miR-548b-3p } \\
\text { miR-562 } \\
\text { miR-587 } \\
\text { miR-588 } \\
\text { miR-612 } \\
\text { miR-619 } \\
\text { miR-647 } \\
\text { miR-652 } \\
\text { miR-668 } \\
\text { miR-760 } \\
\text { miR-885-5p } \\
\text { miR-892b } \\
\text { miR-923 }\end{array}$ \\
\hline MUC4 & $3 q 29$ & $52^{\ddagger}$ & $\begin{array}{l}\text { let-7 family* } \\
\text { miR-10a } \\
\text { miR-122 } \\
\text { miR-138 } \\
\text { miR-139-3p } \\
\text { miR-145 } \\
\text { miR-147, miR-147b } \\
\text { miR-16-1 } \\
\text { miR-193a-3p } \\
\text { miR-197 } \\
\text { miR-199a-5p, } \\
\text { miR-199b-5p } \\
\text { miR-204 } \\
\text { miR-20a* } \\
\text { miR-210 } \\
\text { miR-211 } \\
\text { miR-212 } \\
\text { miR-219-1-3p } \\
\text { miR-297 } \\
\text { miR-324-5p } \\
\text { miR-335 } \\
\text { miR-373 } \\
\text { miR-384 } \\
\text { miR-411 } \\
\text { miR-491-5p } \\
\text { miR-500 } \\
\text { miR-502-3p } \\
\text { miR-548b-5p, } \\
\text { miR-548c-5p }\end{array}$ \\
\hline
\end{tabular}

"Predicted only by miRBase.

Target prediction is based on miRBase and miRanda. The listed miRNAs are predicted by the two prediction programs. 
Mucins: a new family of epigenetic biomarkers in epithelial cancers

Table 2. Predicted miRNA targeting mucin genes (continued).

\begin{tabular}{|c|c|c|c|}
\hline Mucin gene & Chromosomal localization & Number of predicted miRNA & List of iRNA \\
\hline & & & $\begin{array}{l}\text { miR-560 } \\
\text { miR-566 } \\
\text { miR-574-5p } \\
\text { miR-595 } \\
\text { miR-611 } \\
\text { miR-627 } \\
\text { miR-632 } \\
\text { miR-648 } \\
\text { miR-652 } \\
\text { miR-924 } \\
\text { miR-933 } \\
\text { miR-935 } \\
\text { miR-98 }\end{array}$ \\
\hline MUC20 & $3 q 29$ & 15 & $\begin{array}{l}\text { miR-125a-3p } \\
\text { miR-129-3p } \\
\text { miR-205* } \\
\text { miR-222 } \\
\text { miR-326 } \\
\text { miR-330-5p } \\
\text { miR-455-3p, } \\
\text { miR-455-5p } \\
\text { miR-486-3p } \\
\text { miR-552 } \\
\text { miR-588 } \\
\text { miR-603 } \\
\text { miR-611 } \\
\text { miR-622 } \\
\text { miR-647 }\end{array}$ \\
\hline MUC3A/B & $7 q 22$ & 13 & $\begin{array}{l}\text { let-7 family* } \\
\text { miR-154 } \\
\text { miR-196a, } \\
\text { miR-196b } \\
\text { miR-487a } \\
\text { miR-98 }\end{array}$ \\
\hline MUC17 & $7 q 22$ & 7 & $\begin{array}{l}\text { miR-302b, } \\
\text { miR-302c, } \\
\text { miR-302d } \\
\text { miR-450b-3p } \\
\text { miR-486-5p } \\
\text { miR-769-3p } \\
\text { miR-95 }\end{array}$ \\
\hline MUC13 & $3 q 13$ & 16 & $\begin{array}{l}\text { miR-132 } \\
\text { miR-133a, } \\
\text { miR-133b } \\
\text { miR-181a, } \\
\text { miR-181b*, } \\
\text { miR-181c, } \\
\text { miR-181d } \\
\text { miR-211 } \\
\text { miR-30a, miR-30d } \\
\text { miR-335 } \\
\text { miR-485-5p } \\
\text { miR-520d-3p, } \\
\text { miR-520e } \\
\text { miR-543 } \\
\text { miR-633 }\end{array}$ \\
\hline
\end{tabular}

"Predicted only by miRBase.

Target prediction is based on miRBase and miRanda. The listed miRNAs are

predicted by the two prediction programs. 
Table 2. Predicted miRNA targeting mucin genes (continued).

\begin{tabular}{|c|c|c|c|}
\hline Mucin gene & Chromosomal localization & Number of predicted miRNA & List of iRNA \\
\hline & & & $\begin{array}{l}\text { miR-485-5p } \\
\text { miR-520d-3p, } \\
\text { miR-520e } \\
\text { miR-543 } \\
\text { miR-633 }\end{array}$ \\
\hline \multicolumn{4}{|c|}{ Secreted mucins } \\
\hline \multicolumn{4}{|c|}{ 11p15 mucin genes } \\
\hline MUC2 & $11 \mathrm{p} 15$ & $15^{\ddagger}$ & $\begin{array}{l}\text { miR-128a } \\
\text { miR-25* } \\
\text { miR-27a } \\
\text { miR-296-3p } \\
\text { miR-32* } \\
\text { miR-380 } \\
\text { miR-431 } \\
\text { miR-448 } \\
\text { miR-453 } \\
\text { miR-455-5p } \\
\text { miR-512-5p } \\
\text { miR-557 } \\
\text { miR-646 } \\
\text { miR-675 } \\
\text { miR-92b }\end{array}$ \\
\hline MUC5AC & $11 \mathrm{p} 15$ & 10 & $\begin{array}{l}\text { miR-193a-3p, } \\
\text { miR-193b } \\
\text { miR-214* } \\
\text { miR-423-3p } \\
\text { miR-612 } \\
\text { miR-638 } \\
\text { miR-647 } \\
\text { miR-663 } \\
\text { miR-892b } \\
\text { miR-922 }\end{array}$ \\
\hline MUC5B & $11 \mathrm{p} 15$ & 0 & - \\
\hline MUC6 & $11 p 15$ & $23^{\ddagger}$ & $\begin{array}{l}\text { miR-10a } \\
\text { miR-139-3p } \\
\text { miR-146b-3p } \\
\text { miR-184 } \\
\text { miR-206 } \\
\text { miR-298 } \\
\text { miR-323-5p } \\
\text { miR-342-5p } \\
\text { miR-34a } \\
\text { miR-370 } \\
\text { miR-432 } \\
\text { miR-483-5p } \\
\text { miR-485-5p } \\
\text { miR-486-5p } \\
\text { miR-492 } \\
\text { miR-574-5p } \\
\text { miR-585 } \\
\text { miR-592 } \\
\text { miR-595 } \\
\text { miR-616 }\end{array}$ \\
\hline
\end{tabular}

‡Predicted only by miRBase.

Target prediction is based on miRBase and miRanda. The listed miRNAs are predicted by the two prediction programs. 
Mucins: a new family of epigenetic biomarkers in epithelial cancers

Table 2. Predicted miRNA targeting mucin genes (continued).

\begin{tabular}{|c|c|c|c|}
\hline Mucin gene & Chromosomal localization & Number of predicted miRNA & List of iRNA \\
\hline & & & $\begin{array}{l}\text { miR-765 } \\
\text { miR-890 } \\
\text { miR-936 }\end{array}$ \\
\hline \multicolumn{4}{|c|}{ Other secreted mucins } \\
\hline MUC7 & $4 q 13-q 21$ & 2 & $\begin{array}{l}\text { miR-199a-3p } \\
\text { miR-544 }\end{array}$ \\
\hline \multirow[t]{3}{*}{ MUC19 } & $12 q 12$ & 9 & miR-140-5p \\
\hline & & & $\begin{array}{l}\text { miR-146a*, } \\
\text { miR-146b-5p }\end{array}$ \\
\hline & & & miR-29b \\
\hline
\end{tabular}

₹Predicted only by miRBase.

Target prediction is based on miRBase and miRanda. The listed miRNAs are

predicted by the two prediction programs.

Deciphering the epigenetic mechanisms regulating mucin gene expression has been very helpful in understanding mucin gene biology better, but in the future it will provide clinicians and pathologists with new biological tools to screen patients and detect cancer at an early stage as well as classify tumors and propose new therapeutic strategies.

\section{Acknowledgment}

The authors thank F Renaud for tissue section selection.
Declaration of interest

The authors receive financial support from the Institut National de la Santé et de la Recherche Médicale, the Association pour la Recherche contre le Cancer (ARC No. 3872), the Ligue Nationale (Equipe labellisée LIGUE 2008) et Régionale (comités du Nord et du Pas de Calais) Contre le Cancer, the Centre Hospitalier Régional et Universitaire de Lille, the Université de Lille 2 and the Région Nord-Pas de Calais.

\section{Bibliography}

1. Russo VEA, Martienssen RA, Riggs AD. Epigenetic mechanisms of gene regulation. New York: Cold Spring Harbor Laboratory Press, 1996

2. Tost J. Epigenetics. Norfolk: Caister Academic Press, 2008

3. Robertson KD. DNA methylation and human disease. Nat Rev Genet 2005;6(8):597-610

4. Chen T, Ueda Y, Dodge JE, et al. Establishment and maintenance of genomic methylation patterns in mouse embryonic stem cells by Dnmt3a and Dnmt3b. Mol Cell Biol 2003;23(16):5594-605

5. Wilson AS, Power BE, Molloy PL. DNA hypomethylation and human diseases. Biochim Biophys Acta 2007;1775(1):138-62

6. Herman JG, Baylin SB. Gene silencing in cancer in association with promoter hypermethylation. N Engl J Med 2003;349(21):2042-54
7. Razin A. CpG methylation, chromatin structure and gene silencing-a three-way connection. Embo J 1998;17(17):4905-8

8. Cervoni N, Szyf M. Demethylase activity is directed by histone acetylation. J Biol Chem 2001;276(44):40778-87

9. Mutskov V, Felsenfeld G. Silencing of transgene transcription precedes methylation of promoter DNA and histone H3 lysine 9. Embo J 2004;23(1):138-49

10. Bartel DP. MicroRNAs: genomics, biogenesis, mechanism, and function. Cell 2004;116(2):281-97

11. He L, Hannon GJ. MicroRNAs: small RNAs with a big role in gene regulation. Nat Rev Genet 2004;5(7):522-31

12. Wiemer EA. The role of microRNAs in cancer: no small matter. Eur J Cancer 2007;43(10):1529-44

13. Shames DS, Minna JD, Gazdar AF Methods for detecting DNA methylation in tumors: from bench to bedside. Cancer Lett 2007;251(2):187-98
14. Teodoridis JM, Strathdee G, Brown R. Epigenetic silencing mediated by $\mathrm{CpG}$ island methylation: potential as a therapeutic target and as a biomarker. Drug Resist Updat 2004;7(4-5):267-78

15. Palmisano WA, Divine KK, Saccomanno G, et al. Predicting lung cancer by detecting aberrant promoter methylation in sputum. Cancer Res 2000;60(21):5954-8

16. Worm J, Guldberg P. DNA methylation: an epigenetic pathway to cancer and a promising target for anticancer therapy. J Oral Pathol Med 2002;31(8):443-9

17. Strathdee G, Brown R. Epigenetic cancer therapies: DNA methyltransferase inhibitors. Expert Opin Investig Drugs 2002;11(6):747-54

18. Yoo CB, Jones PA. Epigenetic therapy of cancer: past, present and future. Nat Rev Drug Discov 2006;5(1):37-50

19. Liang JJ, Kimchi ET, Staveley-O’Carroll KF, Tan D. Diagnostic and prognostic biomarkers in pancreatic carcinoma. Int J Clin Exp Pathol 2009;2(1):1-10 
20. Van Seuningen I, Pigny P, Perrais M, et al Transcriptional regulation of the $11 \mathrm{p} 15$ mucin genes. Towards new biological tools in human therapy, in inflammatory diseases and cancer? Front Biosci 2001;6:D1216-34

21. Mall AS. Analysis of mucins: role in laboratory diagnosis. J Clin Pathol 2008;61(9):1018-24

22. Leteurtre E, Piessen G, Aubert S, et al. Mucins as diagnostic and/or prognostic factors in epithelial cancers. In: Van Seuningen I, editor, The epithelial mucins: structure/function Roles in cancer and inflammatory diseases. Kerala: Research Signpost; 2008. p. 273-94

23. Pigny P, Guyonnet-Duperat V, Hill AS, et al. Human mucin genes assigned to 11p15.5: identification and organization of a cluster of genes. Genomics 1996;38(3):340-52

24. de Bustros A, Nelkin BD, Silverman A, et al. The short arm of chromosome 11 is a 'hot spot' for hypermethylation in human neoplasia. Proc Natl Acad Sci USA 1988;85(15):5693-7

25. Hollingsworth MA, Swanson BJ. Mucins in cancer: protection and control of the cell surface. Nat Rev Cancer 2004; $4(1): 45-60$

26. Jonckheere N, Van Seuningen I. The ever growing family of membrane-bound mucins. In: Van Seuningen I, editor, The epithelial mucins: structure/function Roles in cancer and inflammatory diseases. Kerala: Research Signpost; 2008. p. 17-38

27. Yonezawa $\mathrm{S}$, Goto M, Yamada N, et al. Expression profiles of MUC1, MUC2, and MUC4 mucins in human neoplasms and their relationship with biological behavior. Proteomics 2008;8(16):3329-41

28. Gicquel C, Rossignol S, Cabrol S, et al. Epimutation of the telomeric imprinting center region on chromosome $11 \mathrm{p} 15$ in Silver-Russell syndrome. Nat Genet 2005;37(9):1003-7

29. Schonherr N, Meyer E, Roos A, et al. The centromeric $11 \mathrm{p} 15$ imprinting centre is also involved in Silver-Russell syndrome. J Med Genet 2007;44(1):59-63

30. Weksberg R, Smith AC, Squire J, Sadowski P. Beckwith-Wiedemann syndrome demonstrates a role for epigenetic control of normal development. Hum Mol Genet 2003;12 Spec No 1:R61-8

31. Craig JM, Bickmore WA. The distribution of $\mathrm{CpG}$ islands in mammalian chromosomes. Nat Genet

1994;7(3):376-82

32. Nakano S, Murakami K, Meguro M, et al. Expression profile of LIT1/KCNQ1OT1 and epigenetic status at the KvDMR1 in colorectal cancers. Cancer Sci 2006;97(11):1147-54

33. Sato N, Matsubayashi $\mathrm{H}$, Abe T, et al. Epigenetic down-regulation of CDKN1C/p57KIP2 in pancreatic ductal neoplasms identified by gene expression profiling. Clin Cancer Res 2005;11(13):4681-8

34. Schwienbacher C, Gramantieri L, Scelfo R, et al. Gain of imprinting at chromosome 11p15: a pathogenetic mechanism identified in human hepatocarcinomas. Proc Natl Acad Sci USA 2000;97(10):5445-9

35. Velcich A, Yang W, Heyer J, et al. Colorectal cancer in mice genetically deficient in the mucin Muc2. Science 2002;295(5560):1726-9

36. Hanski C, Riede E, Gratchev A, et al. MUC2 gene suppression in human colorectal carcinomas and their metastases: in vitro evidence of the modulatory role of DNA methylation. Lab Invest 1997;77(6):685-95

37. Gratchev A, Siedow A, Bumke-Vogt C, et al. Regulation of the intestinal mucin MUC2 gene expression in vivo: evidence for the role of promoter methylation. Cancer Lett 2001;168(1):71-80

38. Siedow A, Szyf M, Gratchev A, et al. De novo expression of the Muc2 gene in pancreas carcinoma cells is triggered by promoter demethylation. Tumour Biol 2002;23(1):54-60

39. Mesquita P, Peixoto AJ, Seruca R, et al. Role of site-specific promoter hypomethylation in aberrant MUC2 mucin expression in mucinous gastric carcinomas. Cancer Lett 2003b;189(2):129-36

40. Hamada T, Goto M, Tsutsumida $\mathrm{H}$, et al. Mapping of the methylation pattern of the MUC2 promoter in pancreatic cancer cell lines, using bisulfite genomic sequencing. Cancer Lett 2005;227(2):175-84

41. Yamada N, Hamada T, Goto M, et al. MUC2 expression is regulated by histone $\mathrm{H} 3$ modification and DNA methylation in pancreatic cancer. Int J Cancer 2006;119(8):1850-7

42. Perrais M, Pigny P, Buisine MP, et al. Aberrant expression of human mucin gene MUC5B in gastric carcinoma and cancer cells. Identification and regulation of a distal promoter. J Biol Chem 2001;276(18):15386-96

43. Ho JJ, Han SW, Pan PL, et al. Methylation status of promoters and expression of MUC2 and MUC5AC mucins in pancreatic cancer cells. Int $\mathrm{J}$ Oncol 2003;22(2):273-9

44. Vincent A, Perrais M, Desseyn JL, et al. Epigenetic regulation (DNA methylation, histone modifications) of the $11 \mathrm{p} 15$ mucin genes (MUC2, MUC5AC, MUC5B, MUC6) in epithelial cancer cells. Oncogene 2007;26(45):6566-76

45. Augenlicht L, Shi L, Mariadason J, et al. Repression of MUC2 gene expression by butyrate, a physiological regulator of intestinal cell maturation. Oncogene 2003;22(32):4983-92

46. Mayo C, Lloreta J, Real FX, Mayol X In vitro differentiation of HT-29 M6 mucus-secreting colon cancer cells involves a trychostatin A and p27(KIP1)-inducible transcriptional program of gene expression. J Cell Physiol 2007;212(1):42-50

47. Smiraglia DJ, Rush LJ, Fruhwald MC, et al. Excessive $\mathrm{CpG}$ island hypermethylation in cancer cell lines versus primary human malignancies. Hum Mol Genet 2001;10(13):1413-9

48. Vincent A, Ducourouble MP, Van Seuningen I. Epigenetic regulation of the human mucin gene MUC4 in epithelial cancer cell lines involves both DNA methylation and histone modifications mediated by DNA methyltransferases and histone deacetylases. FASEB J 2008;22(8):3035-45

49. Jonckheere N, Perrais M, Mariette C, et al. A role for human MUC4 mucin gene, the ErbB2 ligand, as a target of TGF-beta in pancreatic carcinogenesis. Oncogene 2004;23(34):5729-38

50. Singh AP, Chauhan SC, Bafna $S$, et al. Aberrant expression of transmembrane mucins, MUC1 and MUC4, in human prostate carcinomas. Prostate 2006;66(4):421-9

51. Perrais M, Pigny P, Ducourouble MP, et al. Characterization of human mucin gene MUC4 promoter: importance of growth factors and proinflammatory cytokines for its regulation in pancreatic cancer cells. J Biol Chem 2001;276(33):30923-33

52. Fauquette V, Aubert $S$, Groux-Degroote $S$, et al. Transcription factor AP-2alpha represses both the mucin MUC4 expression 
and pancreatic cancer cell proliferation. Carcinogenesis 2007;28(11):2305-12

53. Yamada N, Nishida Y, Tsutsumida $\mathrm{H}$, et al Promoter $\mathrm{CpG}$ methylation in cancer cells contributes to the regulation of MUC4. Br J Cancer 2009

54. Zrihan-Licht S, Weiss M, Keydar I, Wreschner DH. DNA methylation status of the MUC1 gene coding for a breast-cancer-associated protein. Int J Cancer 1995;62(3):245-51

55. Yamada N, Nishida Y, Tsutsumida $H$, et al. MUC1 expression is regulated by DNA methylation and histone $\mathrm{H} 3$ lysine 9 modification in cancer cells. Cancer Res 2008;68(8):2708-16

56. Tost J, Gut IG. DNA methylation analysis by pyrosequencing. Nat Protoc 2007;2(9):2265-75

57. Esteller M. Cancer epigenomics: DNA methylomes and histone-modification maps. Nat Rev Genet 2007;8(4):286-98

58. Zilberman D, Henikoff S. Genome-wide analysis of DNA methylation patterns. Development 2007;134(22):3959-65

59. Omura N, Li CP, Li A, et al. Genome-wide profiling of methylated promoters in pancreatic adenocarcinoma. Cancer Biol Ther 2008;7(7):1146-56

60. Keshet I, Schlesinger Y, Farkash S, et al. Evidence for an instructive mechanism of de novo methylation in cancer cells. Nat Genet 2006;38(2):149-53

61. Taylor KH, Kramer RS, Davis JW, et al. Ultradeep bisulfite sequencing analysis of DNA methylation patterns in multiple gene promoters by 454 sequencing. Cancer Res 2007;67(18):8511-8

62. Massie CE, Mills IG. ChIPping away at gene regulation. EMBO Rep 2008;9(4):337-43

63. Calin GA, Croce CM. MicroRNA signatures in human cancers. Nat Rev Cancer 2006;6(11):857-66

64. Gonzalez S, Pisano DG, Serrano M. Mechanistic principles of chromatin remodeling guided by siRNAs and miRNAs. Cell Cycle 2008;7(16):2601-8

65. Wang H, Ach RA, Curry B. Direct and sensitive miRNA profiling from low-input total RNA. RNA 2007;13(1):151-9

66. Wang Y, Liang Y, Lu Q. MicroRNA epigenetic alterations: predicting biomarkers and therapeutic targets in human diseases. Clin Genet 2008;74(4):307-15
67. Lee YS, Dutta A. MicroRNAs in Cancer. Annu Rev Pathol 2008

68. Zhang B, Farwell MA. microRNAs: a new emerging class of players for disease diagnostics and gene therapy. J Cell Mol Med 2008;12(1):3-21

69. Asangani IA, Rasheed SA, Nikolova DA et al. MicroRNA-21 (miR-21) post-transcriptionally downregulates tumor suppressor Pdcd4 and stimulates invasion, intravasation and metastasis in colorectal cancer. Oncogene 2008;27(15):2128-36

70. Bloomston M, Frankel WL, Petrocca F, et al. MicroRNA expression patterns to differentiate pancreatic adenocarcinoma from normal pancreas and chronic pancreatitis. JAMA 2007;297(17):1901-8

71. Lee EJ, Gusev Y, Jiang J, et al. Expression profiling identifies microRNA signature in pancreatic cancer. Int J Cancer 2007;120(5):1046-54

72. Szafranska AE, Davison TS, John J, et al MicroRNA expression alterations are linked to tumorigenesis and non-neoplastic processes in pancreatic ductal adenocarcinoma. Oncogene 2007;26(30):4442-52

73. Gottardo F, Liu CG, Ferracin M, et al. Micro-RNA profiling in kidney and bladder cancers. Urol Oncol 2007;25(5):387-92

74. Feber A, Xi L, Luketich JD, et al. MicroRNA expression profiles of esophageal cancer.

J Thorac Cardiovasc Surg 2008;135(2):255-60; discussion 60

75. Volinia S, Calin GA, Liu CG, et al. A microRNA expression signature of human solid tumors defines cancer gene targets. Proc Natl Acad Sci USA 2006;103(7):2257-61

76. Mascaux C, Laes JF, Anthoine G, et al. Evolution of microRNAs expression during human bronchial squamous carcinogenesis. Eur Respir J 2008

77. Lujambio A, Calin GA, Villanueva A, et al A microRNA DNA methylation signature for human cancer metastasis. Proc Natl Acad Sci USA 2008;105(36):13556-61

78. Rosenfeld N, Aharonov R, Meiri E, et al. MicroRNAs accurately identify cancer tissue origin. Nat Biotechnol 2008;26(4):462-9

79. Love TM, Moffett HF, Novina CD. Not miR-ly small RNAs: big potential for microRNAs in therapy.
J Allergy Clin Immunol 2008;121(2):309-19

80. Mitchell PS, Parkin RK, Kroh EM, et al. Circulating microRNAs as stable blood-based markers for cancer detection. Proc Natl Acad Sci USA 2008;105(30):10513-8

81. Available from: http://microrna.sanger. ac.uk/targets

82. Available from: http://www.microrna.org

83. Griffiths-Jones $\mathrm{S}$, Grocock RJ, van Dongen $\mathrm{S}$, et al. miRBase: microRNA sequences, targets and gene nomenclature. Nucleic Acids Res 2006;34(Database issue):D140-4

84. John B, Enright AJ, Aravin A, et al. Human MicroRNA targets. PLoS Biol 2004;2(11):e363

85. Ramasamy S, Duraisamy S, Barbashov $S$, et al. The MUC1 and galectin-3 oncoproteins function in a microRNA-dependent regulatory loop. Mol Cell 2007;27(6):992-1004

86. Yu W, Gius D, Onyango P, et al. Epigenetic silencing of tumour suppressor gene $\mathrm{p} 15$ by its antisense RNA. Nature 2008;451(7175):202-6

87. Lapidot M, Pilpel Y. Genome-wide natural antisense transcription: coupling its regulation to its different regulatory mechanisms. EMBO Rep 2006;7(12):1216-22

88. He Y, Vogelstein B, Velculescu VE, et al. The antisense transcriptomes of human cells. Science 2008;322(5909):1855-7

89. Belinsky SA. Gene-promoter hypermethylation as a biomarker in lung cancer. Nat Rev Cancer 2004;4(9):707-17

90. Matsubayashi H, Canto M, Sato N, et al. DNA methylation alterations in the pancreatic juice of patients with suspected pancreatic disease. Cancer Res 2006;66(2):1208-17

91. Schuebel KE, Chen W, Cope L, et al. Comparing the DNA hypermethylome with gene mutations in human colorectal cancer. PLoS Genet 2007;3(9):1709-23

92. Laird PW. The power and the promise of DNA methylation markers. Nat Rev Cancer 2003;3(4):253-66

93. Cairns P, Esteller M, Herman JG, et al. Molecular detection of prostate cancer in urine by GSTP1 hypermethylation. Clin Cancer Res 2001;7(9):2727-30 
94. Kawakami K, Brabender J, Lord RV, et al. Hypermethylated APC DNA in plasma and prognosis of patients with esophageal adenocarcinoma. J Natl Cancer Inst 2000;92(22):1805-11

95. Issa JP. CpG island methylator phenotype in cancer. Nat Rev Cancer 2004;4(12):988-93

96. Shames DS, Girard L, Gao B, et al. A genome-wide screen for promoter methylation in lung cancer identifies novel methylation markers for multiple malignancies. PLoS Med 2006;3(12):e486

97. Mizoshita T, Tsukamoto T, Inada KI, et al. Loss of MUC2 expression correlates with progression along the adenoma-carcinoma sequence pathway as well as de novo carcinogenesis in the colon. Histol Histopathol 2007;22(3):251-60

98. Copin MC, Buisine MP, Devisme L, et al. Normal respiratory mucosa, precursor lesions and lung carcinomas: differential expression of human mucin genes. Front Biosci 2001;6:D1264-75
99. Rakha EA, Boyce RW, Abd El-Rehim D, et al. Expression of mucins (MUC1, MUC2, MUC3, MUC4, MUC5AC and MUC6) and their prognostic significance in human breast cancer. Mod Pathol 2005;18(10):1295-304

100. Swartz MJ, Batra SK, Varshney GC, et al. MUC4 expression increases progressively in pancreatic intraepithelial neoplasia. Am J Clin Pathol 2002;117(5):791-6

101. Byrd JC, Bresalier RS. Mucins and mucin binding proteins in colorectal cancer. Cancer Metastasis Rev 2004;23(1-2):77-99

102. Chaturvedi P, Singh AP, Moniaux N, et al. MUC4 mucin potentiates pancreatic tumor cell proliferation, survival, and invasive properties and interferes with its interaction to extracellular matrix proteins. Mol Cancer Res 2007

103. Esteller M. Epigenetics provides a new generation of oncogenes and tumour-suppressor genes. $\mathrm{Br} \mathrm{J}$ Cancer 2006;94(2):179-83
104. Li Y, Liu D, Chen D, et al. Human DF3/MUC1 carcinoma-associated protein functions as an oncogene. Oncogene 2003;22(38):6107-10

105. Piacentini P, Donadelli M, Costanzo C, et al. Trichostatin A enhances the response of chemotherapeutic agents in inhibiting pancreatic cancer cell proliferation. Virchows Arch 2006;448(6):797-804

106. Van Seuningen I, Perrais M, Pigny P, et al. Sequence of the $5^{\prime}$-flanking region and promoter activity of the human mucin gene MUC5B in different phenotypes of colon cancer cells. Biochem J 2000;348(Pt 3):675-86

\section{Affiliation}

Isabelle Van Seuningen ${ }^{\dagger} \&$ Audrey Vincent ${ }^{\dagger}$ Author for correspondence Jean-Pierre Aubert Research Center, Epithelial Differentiation and Carcinogenesis', Inserm, U837, Team 5 'Mucins,

Place de Verdun, 59045 Lille cedex, France Tel: +33 3202988 67; Fax: +33 32053 85 62;

E-mail: isabelle.vanseuningen@inserm.fr 